\title{
Sensitivity and specificity of current diagnostic guidelines in children with macrophage activation syndrome complicating systemic juvenile idiopathic arthritis
}

\author{
Sergio Davï, Bianca Lattanzi, Silvia Rosina, Erkan Demirkaya, Nicolino Ruperto, Alberto Martini, Randy Q Cron, \\ Angelo Ravelli
}

From 18th Pediatric Rheumatology European Society (PReS) Congress

Bruges, Belgium. 14-18 September 2011

\section{Background}

Early diagnosis of macrophage activations syndrome (MAS) in systemic juvenile idiopathic arthritis (sJIA) may be challenging because it may mimic the clinical features of the underlying disease or be confused with an infectious complication. However, the diagnostic value of the guidelines for hemophagocytic lymphohistiocytosis (HLH) (1) or sJIA-associated MAS (2) has seldom been examined.

\section{Objective}

To investigate the sensitivity and specificity of diagnostic guidelines for HLH and sJIA-associated MAS in patients with sJIA who developed MAS.

\section{Methods}

The study sample included 155 children with sJIA who had MAS (diagnosed and treated as such by the attending physician) and 2 control groups with potentially "confusable" conditions, including active sJIA without MAS ( $\mathrm{n}=303)$ and a systemic febrile infection requiring hospitalization $(n=191)$. Diagnostic guidelines for HLH and sJIA-associated MAS were applied to all MAS and control patients. Because no patient had NK-cell activity and soluble CD25 determination available and bone marrow aspirate was performed in only a few patients, these 3 criteria were excluded from HLH guidelines. HLH criteria were, therefore, met when at least 4 of the 5 remaining variables were present. sJIA-associated

\begin{tabular}{lllll} 
Table & \multicolumn{3}{l}{ MAS vs. active sJIA } & $\begin{array}{l}\text { MAS vs. systemic } \\
\text { infection }\end{array}$ \\
\cline { 2 - 5 } & \multicolumn{5}{l}{\begin{tabular}{l} 
Diagnostic guidelines \\
\cline { 2 - 5 } Sensitivity
\end{tabular}} & Specificity & Sensitivity & Specificity \\
\hline HLH & 0.26 & 1 & 0.26 & 0.98 \\
SJIA-associated MAS & 0.87 & 0.91 & 0.87 & 0.85 \\
\hline
\end{tabular}

MAS criteria were met when at least 2 laboratory criteria or at least 1 laboratory criterion and 1 clinical criterion were present. Sensitivity and specificity of guidelines in discriminating patients with MAS from control patients were assessed.

\section{Results}

The table shows the comparison of sensitivity and specificity of diagnostic guidelines.

\section{Conclusions}

The diagnostic guidelines for sJIA-associated MAS revealed strong sensitivity and specificity, whereas HLH guidelines were highly specific, but lacked sensitivity. Sensitivity of HLH was mostly hampered by the excessive stringent threshold for cytopenia and hypofibrinogenemia, and the infrequent occurrence of splenomegaly in patients with MAS.

Published: 14 September 2011 


\section{References}

1. Henter Jl, Horne A, Aricó M, et al: HLH-2004: Diagnostic and therapeutic guidelines for hemophagocytic lymphohistiocytosis. Pediatr Blood Cancer 2007, 48:124-31.

2. Ravelli A, Magni-Manzoni S, Pistorio A, et al: Preliminary diagnostic guidelines for macrophage activation syndrome complicating systemic juvenile idiopathic arthritis. J Pediatr 2005, 146:598-604.

doi:10.1186/1546-0096-9-S1-P101

Cite this article as: Davi et al.: Sensitivity and specificity of current

diagnostic guidelines in children with macrophage activation syndrome complicating systemic juvenile idiopathic arthritis. Pediatric

Rheumatology 2011 9(Suppl 1):P101.

Submit your next manuscript to BioMed Central and take full advantage of:

- Convenient online submission

- Thorough peer review

- No space constraints or color figure charges

- Immediate publication on acceptance

- Inclusion in PubMed, CAS, Scopus and Google Scholar

- Research which is freely available for redistribution

Submit your manuscript at www.biomedcentral.com/submit
(Ciomed Central 